\title{
Izaak J. de Hulster. Figurines in Achaemenid Period Yehud, Jerusalem's History of Religion and Coroplastics in the Monotheism Debate
}

\section{Astrid Nunn}

\author{
(2) OpenEdition \\ Journals \\ Édition électronique \\ URL : http://journals.openedition.org/abstractairanica/48288 \\ DOI : 10.4000/abstractairanica.48288 \\ ISBN : 1961-960X \\ ISSN : 1961-960X \\ Éditeur : \\ CNRS (UMR 7528 Mondes iraniens et indiens), Éditions de l'IFRI
}

\section{Référence électronique}

Astrid Nunn, « Izaak J. de Hulster. Figurines in Achaemenid Period Yehud, Jerusalem's History of Religion and Coroplastics in the Monotheism Debate », Abstracta Iranica [En ligne], Volume 40-41 | 2019, document 25, mis en ligne le 15 juillet 2019, consulté le 16 avril 2021. URL : http://

journals.openedition.org/abstractairanica/48288; DOI : https://doi.org/10.4000/abstractairanica 48288

Ce document a été généré automatiquement le 16 avril 2021.

Tous droits réservés 


\title{
Izaak J. de Hulster. Figurines in Achaemenid Period Yehud, Jerusalem's History of Religion and Coroplastics in the Monotheism Debate
}

\author{
Astrid Nunn
}

\section{RÉFÉRENCE}

Izaak J. de Hulster. Figurines in Achaemenid Period Yehud, Jerusalem's History of Religion and Coroplastics in the Monotheism Debate. (Orientalische Religionen in der Antike 26).

Tübingen: Mohr Siebeck, 2017, XV+225 p.

1 L'A., s'attache à la question "classique" de la présence ou non de terres cuites figuratives en Judée à l'époque achéménide, tout particulièrement à Jérusalem. Il est généralement reconnu que les nombreuses Judean Pillar Figurines trouvées en Judée remontent au Fer II. Du résultat dépend le regard que l'on jette sur le développement de la religion judaïque. L'A. s'élève contre le paradigme simpliste: absence de figurines signifie présence du judaïsme et bannissement les images. Les 1309 fragments de figurines que Yigal Shiloh a découverts dans sa fouille de la Cité de David (SouthEastern Hill, 1978-1985) sont mis à contribution. Au moins 5 fragments sont définitivement plus récents que le Fer II. $34 \%$ ont été trouvés dans une couche post-Fer II; un lot de 49 figurines provient du Stratum 9 qui est une couche néo-babylonienne et achéménide. Au moins 19 d'entre elles sont achéménides, 6 autres ont été en usage à l'époque achéménide. Ces quelques 30 figurines achéménides ne représentent que 2,3\%, chiffre qui toutefois ne constitue qu'un minimum. En outre, le nombre absolu n'est pas plus bas que dans les autres sites, et, secondement, il est "correct" quand on le juxtapose au faible nombre d'habitants de la Jérusalem achéménide. Il y avait donc non 
seulement des figurines dans la Jérusalem achéménide, mais elles y étaient vraisemblablement fabriquées, ce que corroborent d'autres objets domestiques. Il faut souligner l'attention que l'A. porte sur les traces de couleur signalées sur 158 figurines (p. 89-100).

2 L'A. s'attache ensuite à l'usage de ces Judean Pillar Figurines qui, parce qu'elles représentent des femmes et sont souvent assimilées à des déesses, ont suscité un flux d'études. Même s'il reste imprécis, le contexte domestique dans lequel elles ont été trouvées est un marqueur très important. Le thème subséquent concerne trois mythes identitaires créés de toutes pièces: 1 . "Israël a été purifié pendant l'exil, le monothéisme s'est installé au retour de l'exil, comme le prouve l'absence de figurines. 2. Le "Myth of empty land" et 3. Le "Myth of the mass return".

3 En conclusion, cette monographie bien conduite, parfois (trop) foisonnante quand il s'agit d'idées, de signification et de symbolisme. À vouloir approfondir tant de points, la recherche éclate dans toutes les directions, et reste parfois superficielle. La couleur, champ à multiples facettes, en offre un exemple. Cependant cette importante étude est un élément supplémentaire dans le débat qui déconstruit un certain nombre d'idées reçues sur l'époque achéménide en Israël/Palestine à propos du début du "vrai" judaïsme.

\section{AUTEURS}

\section{ASTRID NUNN}

Université de Munich 